\title{
Mixed Signals on Summary Judgment
}

Howard Wasserman

Florida International University College of Law, howard.wasserman@fiu.edu

Follow this and additional works at: https://ecollections.law.fiu.edu/faculty_publications

Part of the Civil Procedure Commons, Civil Rights and Discrimination Commons, Evidence Commons, Litigation Commons, and the Supreme Court of the United States Commons

\section{Recommended Citation}

Howard Wasserman, Mixed Signals on Summary Judgment Mich. St. L. Rev. 1331 (2014).

Available at: https://ecollections.law.fiu.edu/faculty_publications/193

This Article is brought to you for free and open access by the Faculty Scholarship at eCollections. It has been accepted for inclusion in Faculty Publications by an authorized administrator of eCollections. For more information, please contact lisdavis@fiu.edu. 


\section{HEINONLINE}

Citation: 2014 Mich. St. L. Rev. 13312014

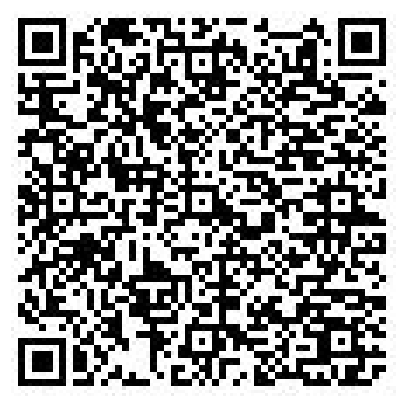

Content downloaded/printed from

HeinOnline (http://heinonline.org)

Tue Oct 13 16:44:26 2015

-- Your use of this HeinOnline PDF indicates your acceptance of HeinOnline's Terms and Conditions of the license agreement available at http://heinonline.org/HOL/License

-- The search text of this PDF is generated from uncorrected OCR text.

-- To obtain permission to use this article beyond the scope of your HeinOnline license, please use:

https://www.copyright.com/ccc/basicSearch.do?

\&operation $=$ go\&search Type $=0$

\&lastSearch $=$ simple\&all $=$ on\&titleOrStdNo $=1087-5468$ 


\title{
MIXED SIGNALS ON SUMMARY JUDGMENT
}

\author{
Howard M. Wasserman*
}

2014 MiCH. ST. L. REV. 1331

\begin{abstract}
This essay examines three cases from the Supreme Court's October Term 2013 addressing the standards for summary judgment. In one case, the Court affirmed summary judgment against a civil-rights plaintiff, in a continued erroneous over-reliance on the certainty of video evidence. In two other cases, the Court rejected the grant of summary judgment against civil-rights plaintiffs, arguably for the first time in quite a while. This essay unpacks the substance and procedure underlying all three decisions and considers the effect of the three cases and what signals they send to lower courts and litigants about the proper approach to summary judgment, particularly in civil-rights cases involving video evidence.
\end{abstract}

TABLE OF CONTENTS

INTRODUCTION 1331

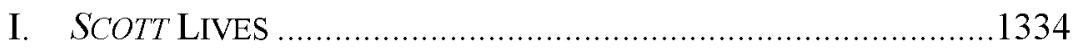

II. Summary Judgment AND PROCEDURAL OdDITIES ..............1340

A. Tolan and Thomas ...................................................1340

B. What Tolan and Thomas Portend ................................1344

III. GOING FORWARD ON SUMMARY JUDGMENT .......................1349

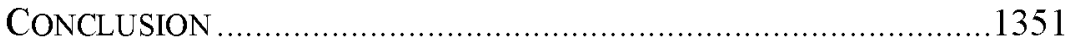

\section{INTRODUCTION}

Since the Supreme Court's 1986 trilogy, ${ }^{1}$ summary judgment has been identified as the great cause of the decline of civil trials.

* Professor of Law, FIU College of Law. This paper was presented in Procedural Hurdles and the Day in Court at the 2014 Southeastern Association of Law Schools Annual Conference; my thanks to all discussion group participants for comments and suggestions. Thanks also to Aaron Bruhl, Kevin Clermont, and John Parry for their reviews and comments. 
Although precise statistics about rates of summary judgment are lacking, ${ }^{2}$ there is a general gestalt that summary judgment has accounted for a rising portion of motions and case dispositions. ${ }^{3}$ Many commentators complain that lower courts too readily grant summary judgment, particularly in favor of defendants and against plaintiffs, and more particularly in civil-rights cases. ${ }^{4}$ Perhaps because the contours and standards of summary judgment's broad reach were established so long ago, however, the Roberts Court has had little to add. Combined with the 2010 amendments to the summary judgment rules that largely bring the rule's text in line with Supreme Court pronouncements and common practice, ${ }^{5}$ summary judgment seems settled and forgotten by the High Court.

By contrast, the Roberts Court has spent far more time on pleading standards and on increasing the role of Rule 12(b)(6) dismissals in weeding out unfounded claims. ${ }^{6}$ And the vast array of empirical analyses of Twombly and Iqbal largely suggests that the Court has been successful in that endeavor. ${ }^{7}$

1. See generally Celotex Corp. v. Catrett, 477 U.S. 316 (1986); Anderson v. Liberty Lobby, Inc., 477 U.S. 242 (1986); Matsushita Elec. Indus. Co. v. Zenith Radio Corp., 475 U.S. 572 (1986).

2. John H. Langbein, The Disappearance of Civil Trial in the United States, 122 YALE L.J. 522, 568-69 (2012).

3. John Bronsteen, Against Summary Judgment, 75 GEO. WASH. L. REV. 522, 523 (2007); Langbein, supra note 2, at 569; Arthur R. Miller, The Pretrial Rush to Judgment: Are the "Litigation Explosion," "Liability Crisis," and Efficiency Clichés Eroding Our Day in Court and Jury Trial Commitments?, 78 N.Y.U. L. REV. 982, 984 (2003); Martin H. Redish, Summary Judgment and the Vanishing Trial: Implications of the Litigation Matrix, 57 STAN. L. REV. 1329, 1330 (2005); Elizabeth M. Schneider, The Changing Shape of Federal Civil Pretrial Practice: The Disparate Impact on Civil Rights and Employment Discrimination Cases, 158 U. PA. L. REV. 517, 548-49 (2010).

4. Bronsteen, supra note 3 , at 539, 542; Schneider, supra note 3 , at 54849.

5. FED. R. CIV. P. 56; FED. R. CIV. P. 56 notes to 2010 Amendments.

6. Fifth Third Bancorp v. Dudenhoeffer, 134 S. Ct. 2459, 2471-73 (2014); Wood v. Moss, 134 S. Ct. 2056, 2067 (2014); Lexmark Int'1 v. Static Control Components, Inc., 134 S. Ct. 1377, 1393-95 (2014); Ashcroft v. Iqbal, 556 U.S. 662, 677-84 (2009); Tellabs, Inc. v. Makor Issues \& Rights, Ltd., 551 U.S. 308, 322-23 (2007); Bell Atl. Corp. v. Twombly, 550 U.S. 544, 570 (2007); see also Ind. State Dist. Council of Laborers \& HOD Carriers Pension \& Welfare Fund v. Omnicare, Inc., 719 F.3d 498, 508 (6th Cir. 2013), cert. granted sub nom Omnicare Inc. v. Laborers Dist. Council Constr. Indus. Pension Fund, 134 S. Ct. 1490 (2014). But see Johnson v. City of Shelby, $\mathrm{S}$. Ct. (2014) (per curiam).

7. Compare Scott Dodson, $\overline{A N e w}$ Look: Dismissal Rates of Federal Civil Claims, 96 JudicAture 127, 127, 132 (2012), Patricia Hatamyar Moore, An Updated Quantitative Study of Iqbal's Impact on 12(b)(6) Motions, 46 U. RICH. L. 
One possible (albeit unstudied) effect of this increased role for $12(b)(6)$ is a decreased role for summary judgment. It is increasingly difficult for plaintiffs to plead a "plausible" non-conclusory claim that can survive a motion to dismiss. And denial of dismissal on qualified immunity grounds in constitutional damages cases is immediately appealable under the collateral order doctrine. ${ }^{8}$ As a result, summary judgment is less essential in disposing of non-trialworthy claims. ${ }^{9}$ Indeed, Iqbal's express goal was to dismiss more civil-rights actions before discovery, with its attendant cost, burden, and distraction on public officials. ${ }^{10}$ Given summary judgment's reliance on discovery, exchange of information, and a full record of evidence to determine whether a case is trial-worthy, ${ }_{11}^{11}$ allowing fewer cases into discovery necessarily means fewer cases will be disposed of on summary judgment.

Prior to October Term 2013, the Roberts Court had decided only one case focused specifically on the standards for summary judgment-Scott v. Harris, an 8-1 decision from 2007, which is most notable for according a unique, perhaps overwhelming role for video evidence on summary judgment. ${ }^{12}$ The Term thus was notable for the

REv. 603, 603 (2012), and Lonny Hoffman, Twombly and Iqbal's Measure: An Assessment of the Federal Judicial Center's Study of Motions to Dismiss, 6 FED. CTS. L. REV. 1, 7 (2012), with William H. J. Hubbard, Testing for Change in Procedural Standards, with Application to Bell Atlantic v. Twombly, 42 J. LEGAL STUD. 35, 35, 57 (2013).

8. Iqbal, 556 U.S. at 672; see also Stephen I. Vladeck, Pendent Appellate Bootstrapping, 16 GREEN BAG 199, 208 (2013) (discussing Iqbal's expansion of immediate appeal under collateral order doctrine).

9. See Theodore Eisenberg \& Kevin M. Clermont, Plaintiphobia in the Supreme Court, 100 CORNELl L. REV. 193, 212 (2014) (discussing studies showing no change in summary judgment rates post-Iqbal, but arguing that "[i]f the parties have adjusted to the new pleading regime, then the cases remaining in the system will exhibit, at least after a while, the same attributes as the pre-Twiqbal caseload"); see also Swierkiewicz v. Sorema N.A., 534 U.S. 506, 512 (2002) (insisting that the Federal Rules rely "on liberal discovery rules and summary judgment motions to define disputed facts and issues and to dispose of unmeritorious claims").

10. Iqbal, 556 U.S. at 685-86.

11. Langbein, supra note 2, at 567-68.

12. Scott v. Harris, 550 U.S. 372, 378-81 (2007); Howard M. Wasserman, Video Evidence and Summary Judgment: The Procedure of Scott v. Harris, 91 JUDICATURE 180, 181 (2008). Summary judgment played an indirect role in Ortiz v. Jordan, 131 S. Ct. 884, 889-90 (2011), where the Court held that a $\$ 1983$ defendant cannot appeal denial of summary judgment on qualified immunity after trial on the merits. The Court also decided two cases addressing substantive liability standards under Title VII of the Civil Rights Act of 1964, but with an express eye toward how those standards allowed for easier pre-trial disposition, particularly on summary judgment. See Univ. of Tex. Sw. Med. Ctr. v. Nassar, 133 S. Ct. 2517, 2532 (2013) 
unexpected return of summary judgment standards to the docket and to the Court's decision making. The Court resolved, in some manner and some procedural context, three cases squarely addressing questions about the proper approach to summary judgment; significantly, all were $\S 1983$ actions involving Fourth Amendment claims of excessive force in which police-officer defendants asserted qualified immunity. ${ }^{13}$ The results were mixed and somewhat procedurally confounded. While one of the cases arguably produced the first summary judgment victory for a civil-rights plaintiff before the Supreme Court in quite some time, another largely reaffirmed Scott's questionable approach to video evidence.

Courts and commentators continue to grapple with vanishing trials and increasing barriers to court access created by the "doublewhammy" of heightened pleading under Iqbal and defendantfriendly summary judgment. ${ }^{14}$ And the peculiar role of video evidence on summary judgment remains a salient issue, ${ }^{15}$ even more so in the wake of video-recorded clashes among media, protesters, and well-armed police in Ferguson, Missouri, and elsewhere throughout summer and fall 2014. ${ }^{16}$ It thus is worth examining all three decisions, and their particular contexts, in search of a better understanding of the present and future of summary judgment as a central tool of civil-rights litigation.

\section{SCOTT LIVES}

Scott v. Harris is most notable for according video evidence a special and uniquely powerful role on summary judgment. The Court insisted that video of a high-speed police chase (taken from the

(insisting that a "lessened causation standard would make it far more difficult to dismiss dubious claims at the summary judgment stage"); Vance v. Ball State Univ., 133 S. Ct. 2434, 2449 (2013) (arguing that supervisor status can be determined before or soon after litigation, or at least resolved on summary judgment); see also Howard Wasserman, The Procedure of Title VII, PRAwFSBlawg (June 24, 2013, 2:21 PM), http://prawfsblawg.blogs.com/prawfsblawg/2013/06/the-procedure-oftitle-vii.html.

13. See Plumhoff v. Rickard, 134 S. Ct. 2012 (2014); Tolan v. Cotton, 134 S. Ct. 1861 (2014) (per curiam); Thomas v. Nugent, 134 S. Ct. 2289 (2014) (mem.).

14. Schneider, supra note 3, at 550.

15. Howard M. Wasserman, Orwell's Vision: Video and the Future of Civil Rights Enforcement, 68 MD. L. REV. 600, 602-07 (2009).

16. Howard M. Wasserman, Moral Panics and Body Cameras, WASH. U. L. REV. COMMENTARIES (Nov. 18, 2014), http://openscholarship.wustl.edu/law_lawreview_commentaries/26. 
pursuing squad car's dashboard camera) "speak[s] for itself," conveying one obvious, neutral, unambiguous, and clear meaning that a court on summary judgment could determine for itself. ${ }^{17}$ Despite Justice Stevens's insistence in dissent that the Court was improperly placing itself in the role of the jurors whose job it is to draw inferences from evidence, ${ }^{18}$ the Court treated the video as capable of only one rational understanding, meaning there was only one rational conclusion a fact finder could reach in the case. More problematically, the Court allowed judges to disregard testimony and other evidence "blatantly contradicted by the record"- that is, contradicted by the video and the singular message a judge on summary judgment gleans from it. ${ }^{19}$ Because video is so conclusive and certain, non-video evidence purporting to contradict it does not create factual disputes; it merely creates a "metaphysical doubt" as to the facts, long recognized as insufficient to avoid summary judgment. ${ }^{20}$

The one fully briefed and argued statement on summary judgment during October Term 2013 was Plumhoff $v$. Rickard, ${ }^{21}$ a case best seen as Scott, the Sequel. Like Scott, Plumhoff was an excessive-force claim arising from a high-speed chase and police use of deadly force to end the chase. ${ }^{22}$ The chase began as a routine traffic stop and continued for some time on the interstate and city streets, with six police cruisers in pursuit. ${ }^{23}$ The chase entered a parking lot, where officers and squad cars surrounded the fleeing vehicle; this paused, and perhaps ended (this was in some dispute), the pursuit. ${ }^{24}$ When the driver did not get out of the car, but instead continued maneuvering the vehicle, police fired fifteen shots into the car; the driver then drove out of the lot and back onto the street before crashing the car into a building. ${ }^{25}$ Both the driver and

17. Scott, 550 U.S. at 378 n.5; Wasserman, supra note 15, at 624-25.

18. Scott, 550 U.S. at 396 (Stevens, J., dissenting) ("If two groups of judges can disagree so vehemently about the nature of the pursuit and the circumstances surrounding that pursuit, it seems eminently likely that a reasonable juror could disagree with this Court's characterization of events."); $i d$. at 389-90 (referring to the Justices as jurors).

19. Id. at 380 (majority opinion).

20. Id. (quoting Matsushita Elec. Indus. Co. v. Zenith Radio Corp., 475 U.S. 574, 586 (1986)); see also Wasserman, supra note 15, at 622-26.

21. 134 S. Ct. 2012 (2014).

22. Id. at 2017-18.

23. Id. at 2017 .

24. Id. at 2017-18.

25. Id. 
passenger, his daughter, died from a combination of gunshot wounds and injuries from the crash. ${ }^{26}$ As in Scott, the entire incident was captured on video from the dashcams of three pursuing police cars. ${ }^{27}$

The Court held in fairly short order (and without dissent) that the defendant officers were entitled to summary judgment. The officers did not violate the plaintiff's constitutional rights by firing fifteen shots at the car because (1) the chase was ongoing, meaning deadly force was justified to end it, and (2) having (properly) decided to use deadly force, the officers were entitled to use however much force was necessary to end the chase. ${ }^{28}$ In any event, the officers were entitled to qualified immunity because even if they used excessive force, it was not clearly established that such force violated the Fourth Amendment, given the absence of nondistinguishable case law finding a violation in using deadly force in similar circumstances. ${ }^{29}$

Plumhoff is a troubling case from the standpoint of any desire to reign in summary judgment, particularly in video cases. But it could have been worse.

The bad of Plumhoff is, as in Scott, over-reliance on video at summary judgment. The Court described at length what "happened" in the chase based solely on its review and interpretation of the video-it characterized the victim's driving as "outrageously reckless"; spoke of cars on the road "forced to alter course" to avoid the cars involved in the pursuit; saw the trapped driver in the parking lot "obviously pushing down on the accelerator because the car's wheels were spinning" while his car's bumper was flush against a police cruiser; and described the fleeing suspect as making "an attempt to escape." "'30 From this, the Court insisted that the "record conclusively disproves respondent's claim that the chase in the present case was already over when [the officers] began shooting." 31

The Court consciously and explicitly grounded its analysis in Scott. While it did not insist that video can "speak for itself" and did

\section{6. $I d$. at 2018 .} 2012).

27. Estate of Allen v. City of W. Memphis, 509 F. App'x 388, 389 (6th Cir.

28. Plumhoff, 134 S. Ct. at 2021-22. Justice Breyer did not join the portion discussing the propriety of firing that many shots, and Justice Ginsburg did not join any part of the opinion finding no Fourth Amendment violation. $I d$. at 2016.

29. Id. at 2024.

30. Id. at 2021 .

31. Id. at 2021-22. 
not include a URL link to the video in the opinion ${ }^{32}$-in fact, the Court never mentioned the video at all-it insisted that there was no reason to reach a different result. ${ }^{33}$ As in Scott, the Court drew conclusions and inferences about what the video showed. The Justices understood the video as necessarily and unavoidably onesided, capable of only one meaning and telling only one unquestionable and unambiguous story-the chase remained ongoing in the parking lot because the driver was still maneuvering his car, meaning he was trying to escape capture. Police thus did not act unreasonably in using deadly force at that point, because the video established that the chase, and thus the ongoing threat to public safety, was not at an end. ${ }^{34}$

The problems with this approach to video evidence on summary judgment have been described at length elsewhere. One is that video cannot, as Scott insisted and Plumhoff assumed, speak for itself. What video actually says depends on a number of different considerations - who and what is depicted, who created the images, and details of the images themselves (such as length, clarity, lighting, distance, angle, scope, steadiness, quality). ${ }^{35}$ These all affect the inferences that can and will be drawn from the video, allowing for many different possible conclusions. ${ }^{36}$ But that uncertainty is precisely why summary judgment is inappropriate in a case such as this, which requires that a fact finder view the video and draw those inferences for itself. ${ }^{37}$

Second, as Dan Kahan and his co-authors famously showed, what a viewer "sees"- and the inferences and conclusions a viewer draws-from video are affected by cultural, demographic, social, political, and ideological characteristics. ${ }^{38}$ Video speaks "only against the background of preexisting understandings of social reality that invest[ed] those facts with meaning." ${ }^{39}$ It thus becomes more essential that the broader range of community voices that

32. See Scott v. Harris, 550 U.S. 372,378 n.5 (2007).

33. Plumhoff, 134 S. Ct. at 2021.

34. Id. at 2021-22.

35. Wasserman, supra note 15 , at 620; Wasserman, supra note 16.

36. Wasserman, supra note 15 , at 620 .

37. Id. at 618-21; Wasserman, supra note 12, at 182-83.

38. Dan M. Kahan, David A. Hoffman \& Donald Braman, Whose Eyes Are You Going to Believe? Scott v. Harris and the Perils of Cognitive Illiberalism, 122 HARV. L. REV. 837, 879 (2009); see also Wasserman, supra note 15, at 627.

39. Kahan, Hoffman \& Braman, supra note 38 , at 883. 
comprise a jury be given an opportunity to review and draw inferences from the video.

Unfortunately, Plumhoff demonstrates that the Court has not taken those lessons to heart. Nor have lower courts, which routinely grant summary judgment for defendants ${ }^{40}$ and sometimes even for plaintiffs, ${ }^{41}$ solely on judicial conclusions about video. Plumhoff validates and sanctions what courts have been doing, reaffirming this erroneous approach to video evidence and to summary judgment.

Indeed, Plumhoff goes one step further in that the Court never mentioned video as part of the record, even as it relied on it almost exclusively; we know there was video in the record only from the lower court opinion ${ }^{42}$ and because the attorneys referred to it during oral argument. ${ }^{43}$ Justice Alito simply recited the facts, described "what happened" during the chase and in the parking lot, and characterized the events, without identifying the video or any piece of evidence supporting those conclusions. The insistence that Scott controls the result hints that this is a video case, but the Court hardly made that clear.

So why was Plumhoff not as bad as it might have been? Unlike Scott, the Court did not ignore testimony and other non-video record evidence in favor of the video. Since both the driver and passenger were killed, neither could offer testimony about the events that the Justices could then compare with their view of the video and disregard as contradicted. ${ }^{44}$ The only evidence was the video and the officers' testimony (which was consistent with the video), thus the Court did not have the opportunity to favor some evidence over other

40. See, e.g., Marvin v. City of Taylor, 509 F.3d 234, 248-49 (6th Cir. 2007); Mecham v. Frazier, 500 F.3d 1200, 1202 n.2 (10th Cir. 2007); White v. United States, 863 F. Supp. 2d 41, 49 (D.D.C. 2012) (describing "unbiased video evidence" as basis for court to reject plaintiffs' version of events); Marion v. City of Corydon, Ind., No. 4:07-cv-0003-DFH-WGH, 2008 WL 763211, at*1 \& n.1 (S.D. Ind. Mar. 20, 2008). But see Witt v. W. Va. State Police, Troop 2, 633 F.3d 272, 277 (4th Cir. 2011) (finding video not sufficiently conclusive to override contrary testimony, where video was of poor quality, lacked sound, and had several seconds missing).

2012)

41. Hulstedt v. City of Scottsdale, 884 F. Supp. 2d 972, 982 (D. Ariz.

42. Estate of Allen v. City of W. Memphis, 509 F. App'x 388, 389 (6th Cir. 2012).

43. Transcript of Oral Argument at 12, Plumhoff v. Rickard, $134 \mathrm{~S}$. Ct.

2012 (2014) (No. 12-1117), available at

http://www.supremecourt.gov/oral_arguments/argument_transcripts/12-

1117 f2ag.pdf (describing what the video "indisputably shows").

44. Plumhoff, 134 S. Ct. at 2018. 
evidence. While the power of a court to disregard evidence that is "blatantly contradicted by the record" was a repeated theme during Plumhoff arguments, ${ }^{45}$ it never came up in the opinion itself. The conflict here involved competing arguments about one piece of evidence - the video- and the reasonable inferences that could be drawn from it about whether the chase already had ended when police began shooting. Identifying only a single reasonable inference from the video is, normatively, the wrong approach to summary judgment. But it at least is preferable to a summary judgment court entirely ignoring some record evidence in favor of other record evidence and weighing and preferring video evidence over other available evidence.

Getting courts to understand and appropriately handle video evidence on summary judgment in civil-rights litigation is only going to become more important going forward ${ }^{46}$ In August 2014, the town of Ferguson, Missouri, exploded over a fatal police shooting and massive and violent police response to subsequent public protests, much captured and replayed on video. ${ }^{47}$ At around the same time, video captured the apparent use of a chokehold by a New York City police officer resulting in an arrestee's death. ${ }^{48}$ Other video-recorded police-citizen conflicts have been replayed across the Internet. ${ }^{49}$ At

45. Transcript of Oral Argument, supra note 43, at 22.

46. Compare Gillis v. Pollard, 554 F. App'x. 502, 504 (7th Cir. 2014) (holding that there was no triable fact where the video contradicted the plaintiff's testimony about having been struck in the groin), with Edwards v. Byrd, $750 \mathrm{~F} .3 \mathrm{~d}$ 728,733 (8th Cir. 2014) (stating that the video was not as conclusive as in Scott, justifying denial of summary judgment in favor of the defendant).

47. Wasserman, supra note 16.

48. Joseph Goldstein \& Marc Santora, Staten Island Man Died from Chokehold During Arrest, Autopsy Finds, N.Y. TIMES (Aug. 1, 2014), $\mathrm{http}: / / \mathrm{www}$.nytimes.com/2014/08/02/nyregion/staten-island-man-died-fromofficers-chokehold-autopsy-finds.html?_r=0.

49. Daniel Politi, L.A. Police $\bar{C}$ aught on Video Shooting Homeless Man to Death, SLATE (Mar. 1, 2015, 11:53 PM), http://www.slate.com/blogs/the_slatest/ 2015/03/01/video_shows_lapd_shooting_and_killing_homeless_man.html; $\quad$ Ed Mazza, Sean Groubert, South Carolina State Trooper, Fired \& Arrested After Shooting Unarmed Man, HufFington Post (Sept. 25, 2014, 8:59 AM), http://www.huffingtonpost.com/2014/09/25/sean-groubert-fired-arrested_n_5879694 .html; Ben Mathis-Lilley, "I'm Not Your Brother," Says Officer Tasering Black Minnesota Man in Front of His Children, SLATE (Aug. 29, 2014, 9:42 AM), $\mathrm{http}: / / \mathrm{www}$.slate.com/blogs/the_slatest/2014/08/29/minnesota_taser_video_christop her_lollie_of_st_paul_tased_in_front_of_children.html; Howard Wasserman, Determining the Effect of Video, PRAWFSBLAwg (July 8, 2014, 9:31 AM), http://prawfsblawg.blogs.com/prawfsblawg/2014/07/determining-the-effect-ofvideo.html. 
the same time, President Obama and a significant portion of the public now favor equipping police with body cameras. ${ }^{50}$

The result of these efforts will be an increasing amount of video evidence in an increasing amount of civil-rights litigation arising from police-citizen altercations. That, in turn, highlights the need for courts to pull back from the mistaken overreliance on video evidence reflected in the summary judgment analyses in Plumhoff and Scott.

\section{Summary Judgment AND PROCEDURAL OdDITIES}

\section{A. Tolan and Thomas}

In light of Plumhoff and Scott, and the overall trend on summary judgment (and pre-trial resolution generally), it becomes harder to know what to make of two other cases from late in the Term.

In Tolan v. Cotton, the Court, in a single order accompanied by a per curiam opinion, granted certiorari from the Fifth Circuit, vacated a decision granting summary judgment for the police officer defendant, and remanded for further consideration. ${ }^{51}$ Prior to this decision, the Court had relisted the case for conference nine times. ${ }^{52}$

Tolan arose from a police stop gone bad and what can charitably be described as a combination of overzealous policing, angry and offended homeowners, and negligent typing. A police officer saw a car pull in front of a house and ran the license plate; unfortunately, he entered the wrong plate number (he mistyped one digit), and the computer reported a stolen vehicle of that make and model. ${ }^{53} \mathrm{He}$ drew his weapon and ordered both Tolan (the driver) and his companion to lie on the ground on the front porch of the house, accusing them of having stolen the car. ${ }^{54}$ Tolan's parents came outside and attempted to explain that they owned both the

50. Wasserman, supra note 16; Howard M. Wasserman, Epilogue: Moral Panics and Body Cameras, Wash. U. L. Rev. Commentaries (Jan. 1, 2015), http://openscholarship.wustl.edu/law_lawreview_commentaries/27; see also INTERIM REPORT OF THE PRESIDENT'S TASK FORCE ON 21ST CENTURY POLICING, PRESIDENT'S TASK FORCE ON 21ST CENTURY POLICING (2015), available at http://www.cops.usdoj.gov/pdf/taskforce/Interim_TF_Report.pdf.

51. 134 S. Ct. 1861 (2014) (per curiam).

52. Tolan v. Cotton, SCOTUSBLOG, http://www.scotusblog.com/casefiles/cases/tolan-v-cotton/ (last visited Dec. 27, 2014).

53. Tolan, $134 \mathrm{~S}$. Ct. at 1863.

54. Id. 
house and the car and that one of the men was their son. ${ }^{55} \mathrm{~A}$ second officer, Sergeant Jeffrey Cotton, arrived at the scene; the first officer explained that he had seen the two men exit a stolen car, while Tolan's parents reiterated that there was no theft and they owned the property at issue ${ }^{56}$ Cotton then ordered Tolan's mother to stand by the garage door and physically moved her in that direction, although the amount of force is disputed ${ }^{57}$ Seeing that, Tolan rose either to his knees or his feet (another disputed fact) and told the officer to " $[\mathrm{G}]$ et your fucking hands off my mom" (his words are undisputed).$^{58}$ At that point, Cotton pulled his weapon and shot Tolan three times in the chest. ${ }^{59}$ Tolan survived, although he suffered injuries that interrupted a promising baseball career. ${ }^{60}$

In the subsequent $\& 1983$ action,${ }^{61}$ the Fifth Circuit had affirmed the district court's grant of summary judgment on Tolan's constitutional claim, concluding that even if Cotton violated the Fourth Amendment in using deadly force, he was entitled to qualified immunity because it was not clearly established that an officer violates the Fourth Amendment in using deadly force given the facts and circumstances at hand. ${ }^{62}$

But the Supreme Court rejected that conclusion. When deciding whether a right is clearly established for the second prong of the qualified immunity analysis, a court must define the right "on the basis of the "specific context of the case." "63 It is not enough, for example, that a right against the use of unreasonable force is clearly established; the question is whether it is clearly established that this right is violated by the use of particular force in particular circumstances in light of particular facts. ${ }^{64}$ In doing so, however, courts "must take care not to define a case's 'context' in a manner that imports genuinely disputed factual propositions." 65

55. Id.

56. Id. at 1864.

57. Id.

58. Id. (alteration in original) (citation omitted).

59. Id.

60. Id.

61. Sergeant Cotton was acquitted on state charges of aggravated assault by a public servant. $I d$. at $1864 \mathrm{n} .1$ (citing Tolan v. Cotton, 713 F.3d 299, 303 (5th Cir. 2013)).

62. Tolan, 713 F.3d at $301,306,308$.

63. Tolan, 134 S. Ct at 1866 (quoting Saucier v. Katz, 533 U.S. 194, 201 (2001)).

64. Anderson v. Creighton, 483 U.S. 635, 639-41 (1987).

65. Tolan, $134 \mathrm{~S}$. Ct. at 1866. 
The context in this case, according to the Fifth Circuit, was that (1) the area in which the encounter took place was "dimly-lit"; (2) "Tolan's mother "refus[ed] [repeated] orders to remain quiet and calm""; (3) Tolan was "shouting" and being "verbally threatening" in telling Cotton to get his "fucking hands" off Tolan's mother; and (4) Tolan had risen to his feet and was moving towards Cotton. ${ }^{66}$ On those facts and in this context, it was not clearly established that Cotton was unreasonable in using deadly force.

But, the Supreme Court insisted, the Fifth Circuit defined the context only by impermissibly weighing evidence and failing to credit competing evidence. ${ }^{67}$ Instead, the Court specifically identified record evidence contradicting all four facts. ${ }^{68}$ Tolan and his parents testified that a gas porch lamp was more than decorative and did give off light and that there were floodlights and motion-activated lights in front of the house. ${ }^{69}$ Tolan's mother testified that she was insistent, but neither agitated nor aggravated in speaking to Cotton. ${ }^{70}$ Tolan testified that he was not screaming. And although he did use an expletive, a reasonable juror could infer that those words reflected a plea rather than a threat, especially in light of further testimony that Cotton used significant force in moving Tolan's mother and pushing her against the garage. ${ }^{71}$ Finally, Tolan testified that he was on his knees, not his feet, and "wasn't going anywhere."'72 This contradictory testimony created factual disputes, making it impossible to identify a specific factual context in defining the right at issue for qualified immunity purposes.

The Fifth Circuit erred in not properly crediting the plaintiffs' contrary testimonial evidence. But reasoning that there might be other facts suggesting the reasonableness of the defendant's conduct in that factual context, the Court remanded so the lower court could credit this evidence and draw inferences in the plaintiffs' favor, then decide anew whether Cotton violated clearly established rights. ${ }^{73}$ $305-08)$

66. Id. at $1866-68$ (first alteration in original) (quoting Tolan, $713 \mathrm{~F} .3 \mathrm{~d}$ at

67. Id. at 1866.

68. Id. at 1866-67.

69. Id.

70. Id. at $\mathbf{1 8 6 7 .}$

71. Id.

72. Id. at 1867 (citation omitted).

73. Id. at 1868 . 
Two weeks later, the Court issued an explicit summary Grant, Vacate, and Remand (GVR) order in Thomas v. Nugent, another Fifth Circuit decision, for reconsideration in light of Tolan ${ }^{74}$ Thomas also was a $\S 1983$ action seeking damages for excessive force under the Fourth Amendment, with the defendant officer asserting qualified immunity. ${ }^{75}$ This case arose from the death of an arrestee who was tased eight times by an officer attempting to bring him into custody on an outstanding warrant; after several shots, the victim stood and wandered around the area, then dropped to the ground, crying for police to leave him alone so he could die. ${ }^{76} \mathrm{~A}$ similar scene later played when the victim got out of the car at the police station. The victim apparently died from complications of sickle cell anemia triggered by use of the Taser. ${ }^{77}$

As in Tolan, the Fifth Circuit had held that the officer was entitled to summary judgment on qualified immunity because it was not clearly established that the Fourth Amendment was violated on the facts and circumstances at hand.$^{78}$ And as in Tolan, the court of appeals defined the specific context, allowing it to distinguish prior precedent that might have served to clearly establish the right. ${ }^{79}$

It is not clear from either the Fifth Circuit's per curiam opinion or the Supreme Court's GVR order what facts might have been in genuine dispute. The most likely problem was the lower court's conclusion that the decedent "attempted to evade arrest, was subdued only through the threat of deadly force, and did not comply with the officers' repeated requests to cooperate in effectuating the arrest." 80 With the context so defined, the use of the Taser did not involve the type of "obvious" violation that might be clearly established even without a body of case law. ${ }^{81}$ But the basic facts as recited earlier in the opinion at least potentially suggested not a threatening person resisting arrest, but someone suffering from significant physical and mental health problems. In fact, in denying summary judgment for the defendant on the excessive force claim, the district court had emphasized evidence that the decedent was "crying out for help," as well as uncertainty about what the decedent was doing and whether

74. Thomas v. Nugent, 134 S. Ct. 2289 (2014) (mem.).

75. Thomas v. Nugent, 539 F. App'x 456, 456 (5th Cir. 2013) (per curiam).

76. Id. at $456-57$.

77. Id. at 458 .

78. Id. at 459 .

79. Id.

80. Id. at 461 .

81. Id. 
he truly posed a threat to the officers when each subsequent Taser burst was administered ${ }^{82}$

The Fifth Circuit also did not consider a different inference favorable to the plaintiff - that his physical and mental problems and failure to comply, purportedly justifying subsequent Taser shots, might have been caused by the earlier shots themselves, particularly the third, which was at a higher intensity level. In other words, the officer's initial uses of the Taser produced the very non-compliant behavior that purportedly justified the subsequent uses. Finally, potential disputes surrounded that single higher-intensity shot-both whether the officer intended to do so (the Fifth Circuit concluded he did not, although it cited no record evidence) and whether that severity provided an alternative explanation for the decedent's subsequent continued non-compliance.

\section{B. What Tolan and Thomas Portend}

Ed Brunet and John Parry praise Tolan as the first time in many years that a civil-rights plaintiff prevailed before the Supreme Court on summary judgment ${ }^{83}$ It thus is "tempting to [see it] as a major summary judgment decision" marking at least a slight move from a long-standing defense-centric approach to Rule $56 .{ }^{84}$ Indeed, the Court closed the opinion with a rousing paean to the benefits of trial and the limits of summary judgment:

The witnesses on both sides come to this case with their own perceptions, recollections, and even potential biases. It is in part for that reason that genuine disputes are generally resolved by juries in our adversarial system. By weighing the evidence and reaching factual inferences contrary to Tolan's competent evidence, the court below neglected to adhere to the fundamental principle that at the summary judgment stage, reasonable inferences should be drawn in favor of the nonmoving party. ${ }^{85}$

This is a strong statement, reminiscent of Justice Black's criticism of "trial by affidavit and the sterile bareness of summary judgment."

82. Thomas v. City of Winnfield, No. 08-1167, 2012 WL 1255265, at *10 (W.D. La. Apr. 13, 2012).

83. Ed Brunet \& John Parry, Guest Post: Brunet and Parry on Tolan v. Cotton, Civ. Proc. \& FED. CTS. BlOG (May 8, 2014), http://lawprofessors.typepad.com/civpro/2014/05/guest-post-brunet-and-parry-ontolan-v-cotton.html.

84. Id.

85. Tolan v. Cotton, 134 S. Ct. 1861, 1868 (2014) (per curiam).

86. Adickes v. S.H. Kress \& Co., 398 U.S. 144, 176 (1970) (Black, J., concurring in the judgment). 
Brunet and Parry suggest Tolan might "embolden" lower courts to be more receptive to identifying factual disputes. ${ }^{87}$ There was no sense in Tolan that the testimony of Tolan or his parents ever could or should be ignored simply because it was "contradicted" by other evidence. Indeed, that seems to be the point-there was a genuine dispute of fact precisely because the officer and the plaintiff and his parents told conflicting stories. Nor did the Court suggest that a dispute over seemingly minor background inferences (for example, the amount of illumination from the gas porch lamp) was not material or that it created nothing more than "metaphysical doubt" about the facts. ${ }^{88}$ All of this is consistent with a normatively appropriate approach to summary judgment. But it is somewhat in conflict with Scott, where the Court did not hesitate to weigh video above all other evidence, and with Plumhoff (decided three weeks after Tolan), where video evidence was deemed sufficient on its own to warrant summary judgment with no consideration for the possibility of competing inferences from that video.

One important question is why the Supreme Court handled Tolan as it did and the effect of those procedural choices on the decision's precedential force. The Court granted cert, vacated, and remanded in a single order with a per curiam opinion, based only on the cert. papers, without merits briefing, argument, or full consideration.

The best explanation is that Tolan was a simple case involving established precedent and a circuit court opinion grounded in a "clear misapprehension of summary judgment standards in light of our precedents." ${ }^{\prime \prime 9}$ The case did not require discussion or elaboration of new legal principles, so plenary consideration was unnecessary. The law already was clear that courts on summary judgment cannot resolve factual disputes when defining the specific context of a clearly established right for qualified immunity purposes; without establishing new law, the Court simply reminded lower courts of the proper existing standards and their obligations under those standards. The law also was clear that courts on summary judgment are not to weigh evidence or favor some testimony over other testimony. The subsequent Thomas GVR puts a fine point on this-the Court presumed that the Fifth Circuit had similarly "misapprehended"

87. Brunet \& Parry, supra note 83.

88. Scott v. Harris, 550 U.S. 372, 380 (2007) (quoting Matsushita Elec. Indus. Co. v. Zenith Radio Corp., 475 U.S. 574, 586 (1986)).

89. Tolan, $134 \mathrm{~S}$. Ct at 1868. 
established summary-judgment standards, so it remanded for the lower court to take another look, without even bothering to do it itself. ${ }^{90}$

The decisions together perform a signaling function, telling other circuits that they could be next, so proceed with caution. They reflect the Supreme Court supervising lower courts and pulling outliers back into line when they move too far afield. ${ }^{91}$ In addition, Judge Dennis sharply dissented from the Fifth Circuit denial of rehearing en banc in Tolan, ${ }^{92}$ an opinion that the Supreme Court's per curiam closely tracked. ${ }^{93}$

But this explanation raises several concerns. First, it opens the door to the criticism in the separate opinion by Justice Alito, joined by Justice Scalia. Justice Alito argued that Tolan involved little more than routine consideration of the sufficiency of evidence in the summary judgment record and thus was not an appropriate case for even summary Supreme Court review. ${ }^{94}$

Second, this explanation dampens the force of this rare summary judgment victory for a civil-rights plaintiff. The Court has suggested that per curiam summary dispositions are of more limited precedential force than cases resolved on the merits following full briefing and oral argument, at least for the Court itself. ${ }^{95}$ And while some per curiam opinions have become significant precedents, these

90. Or, as one anonymous blog commentator put it, "So if the holding of Tolan is 'remember the basic concept of summary judgment, dummy,' then Thomas $v$ Nugent seems to stand for the proposition 'you probably did it again, dummy, but your work was so sloppy that we're not even going to check it until you rewrite it." See Howard Wasserman, Two Procedural Cases of Note, PrawfsBlawg (May 20, 2014, 9:31 AM), http://prawfsblawg.blogs.com/prawfsblawg/2014/05/twoprocedural-cases-of-note. $h t m l$.

91. SuP. CT. R. 10(a); Glenn H. Reynolds \& Brannon P. Denning, what Hath Raich Wrought? Five Takes, 9 LEwIS \& ClARK L. REV. 915, 920 (2005) (discussing the Supreme Court's role in supervising lower courts on substantive law); see also, e.g., Hardy v. Cross, 132 S. Ct. 490, 495 (2011) (per curiam) (summarily granting cert. and reversing where the court of appeals failed to accord sufficient deference to the state court under the Antiterrorism and Effective Death Penalty Act).

92. Tolan v. Cotton, 538 F. App'x 374 (5th Cir. 2013) (Dennis, J., dissenting from denial of rehearing en banc).

93. Tolan, $134 \mathrm{~S}$. Ct. at $\mathbf{1 8 6 3}$.

94. Id. at 1868-69 (Alito, J., concurring).

95. See U.S. Bancorp Mortg. Co. v. Bonner Mall P'ship, 513 U.S. 18, 24 (1994); Gray v. Mississippi, 481 U.S. 648, 651 n.1 (1987); Edelman v. Jordan, 415 U.S. 651, 671 (1974). 
were issued after full briefing, argument, and consideration. ${ }^{96}$ Future civil-rights plaintiffs facing a qualified immunity defense certainly can point to Tolan "nudging" lower courts to be cautious about finding facts or resolving conflicting evidence on summary judgment, especially in defining the factual context of a right on the "clearly established" prong of qualified immunity analysis. That the Tolan Court took the time to identify the Fifth Circuit's errors and the obvious factual and evidentiary disputes, rather than summarily vacating and remanding, might suggest a shift in the Court's attitude towards summary judgment. But future plaintiffs lack that fullthroated statement that would have carried more persuasive force, especially given Tolan's egregious facts.

Of course, this odd posture may have been necessary to produce a majority. Perhaps the nine relistings were a result of internal wrangling. Justices Alito and Scalia did not believe the case cert.-worthy, while insisting they were not dissenting from the grant of certiorari, which itself runs contrary to common Court practice. ${ }^{97}$ A per curiam opinion of more limited precedential force may have been the preferable option for the other Justices over outright denial of cert.

Third, even accepting that the procedural choices reflect necessary internal compromise, it is difficult to reconcile summary per curiam disposition in Tolan with the GVR in Thomas. A summary reversal corrects a "clear misapprehension" of controlling law, ${ }^{98}$ which the Court expressly identified as a basis for intervening Tolan. ${ }^{99} \mathrm{~A}$ GVR is appropriate where

intervening developments, or recent developments that we have reason to believe the court below did not fully consider, reveal a reasonable probability that the decision below rests upon a premise that the lower court would reject if given the opportunity for further consideration, and

96. See generally, e.g., Bush v. Gore, 531 U.S. 98 (2000) (per curiam); Buckley v. Valeo, 424 U.S. 1 (1976) (per curiam); Brandenburg v. Ohio, 395 U.S. 444 (1969) (per curiam). For example, it is widely recognized that Justice Abe Fortas had drafted and circulated an opinion in his name in Brandenburg, but it had not been released when he resigned in May 1969. Justice William Brennan then took over the opinion, made some key language changes, and released it as a per curiam. Seth Stern \& Stephen Wermiel, Justice Brennan: Liberal Champion 318 (2010).

97. Tolan, 134 S. Ct. at 1869 (Alito, J., concurring).

98. Brosseau v. Haugen, 543 U.S. 194, 198 n.3 (2004) (per curiam).

99. Tolan, $134 \mathrm{~S}$. Ct. at 1868. 
where it appears that such a redetermination may determine the ultimate outcome of the litigation. ${ }^{100}$

That intervening development is most frequently a new decision from the Supreme Court. ${ }^{101}$ Summary reversals and GVRs are complementary ways for the Court to correct obvious lower-court error without the burdens of plenary review; the latter offers a "cautious and deferential alternative" to the former, ${ }^{102}$ allowing the lower court an opportunity to look for and correct its own error in light of intervening legal developments, rather than having the Supreme Court do it for them. ${ }^{103}$

While Thomas was an express GVR, Tolan is a bit harder to characterize. Although by its terms it did grant, vacate, and remand, it is not a typical GVR, which (as in Thomas) generally consists of a "few boilerplate lines." 104 Tolan better fits with not-uncommon orders that formally vacate but for all practical purposes summarily reverse-the Court finds that the lower court applied the wrong standard, but rather than applying the correct standard itself, remands for the lower court to do it. ${ }^{105} \mathrm{By}$ including the per curiam, however, the Court appears to have done more-it applied the proper standard itself to show how the facts underlying the context of the case were disputed and how that undermined the grant of summary judgment. But it still remanded to give the lower court another chance to consider whether other facts nevertheless justified the original outcome. ${ }^{106}$

Tolan's procedural posture also means the Thomas GVR ordering reconsideration in light of Tolan makes no sense. If Tolan was appropriate as summary reversal ${ }^{107}$ correcting a clear and obvious misapprehension of established precedent, it cannot function

100. Lawrence ex rel. Lawrence v. Chater, 516 U.S. 163, 167 (1996) (per curiam); cf. Aaron-Andrew P. Bruhl, The Supreme Court's Controversial GVRs and an Alternative, 107 MiCH. L. REV. 711, 712 (2009).

101. Bruhl, supra note 100 , at 712 .

102. Lawrence, 516 U.S. at 168.

103. Bruhl, supra note 100 , at 712 .

104. Id. at 717 .

105. Id. at $717 \&$ n.19; see also, e.g., Ash v. Tyson Foods, Inc., 546 U.S. 454, 456 (2006) (per curiam).

106. Compare id., with Stanton v. Sims, 134 S. Ct. 3, 4, 7 (2013) (per curiam) (granting certiorari, reversing, and remanding in a Fourth Amendment excessive force case, where any right was not clearly established, regardless of whether a violation had occurred).

107. See Bruhl, supra note 100, at 717 (identifying similar cases with per curiam opinions as summary reversals rather than GVRs). 
as an intervening or recent development in the law that the Fifth Circuit panel in Thomas did not have an opportunity to consider. The Fifth Circuit in Thomas knew the existing summary judgment precedents and standards; nothing in Tolan purported to change those or to tell the lower court something it did not already know about the law of summary judgment. Tolan and Thomas thus stand on the same footing - in both, the Fifth Circuit was either right or wrong in its understanding and application of existing established summary judgment law. It follows that the cases should have been resolved in identical procedural fashion-either Thomas should have been summarily reversed with a per curiam, as in Tolan, or cert. should have been denied in both as simple cases involving the sufficiency of the evidence on summary judgment, as Justice Alito argued should have happened in Tolan. ${ }^{108}$

One perhaps could try to use the Thomas GVR to give Tolan greater precedential heft. That is, if Tolan qualifies as an intervening development making the Thomas GVR appropriate (and no one recorded a dissent from the GVR), then Tolan becomes something more than an ordinary summary reversal-a fuller, even if per curiam, statement on the proper scope of, and approach to, summary judgment on qualified immunity in civil-rights actions.

\section{GOING FORWARD ON SUMMARY JUDGMENT}

The remaining question is the takeaway from all of the Supreme Court's activity in October Term 2013, particularly the different attitudes towards summary judgment reflected in Plumhoff on the one hand and Tolan and Thomas on the other.

An easy, albeit unfortunate, answer is that Plumhoff was a video case and Tolan was not. Perhaps adding video to the record in Tolan would have fundamentally changed the analysis and outcome. Had there been a dashboard camera or police body camera ${ }^{109}$ filming the events in front of the Tolan home, the Court might have watched the video and concluded for itself that (1) the porch and front of the house were "dimly-lit"”; (2) Tolan's mother was loud and agitated and ignored repeated orders to calm down; (3) Tolan was

108. Tolan, 134 S. Ct. at 1868-69 (Alito, J., concurring).

109. See Wasserman, supra note 16; Wasserman, supra note 50; see also generally POLICE EXEC. RESEARCH FORUM, IMPLEMENTING A BODY-WORN CAMERA PROGRAM: RECOMMENDATIONS AND LESSONS LEARNED (2014), available at http://www.policeforum.org/assets/docs/Free_Online_Documents/Technology/imple menting\%20a\%20body-worn\%20camera\%20program.pdf; 
"shouting" and being "verbally threatening"" in telling Cotton to get his "fucking hands" off Tolan's mother while Cotton used only minimal force against her; and (4) Tolan was moving towards Cotton. ${ }^{110}$ And the contrary testimony of Tolan and his parents on each of those points could have been disregarded as "blatantly contradicted" by the inferences the Justices drew for themselves from watching the video. In other words, the Court might have used the video to make the same factual findings as the Fifth Circuit panel. Plumhoff, like Scott, reflects the irresistible urge to overvalue video on summary judgment. There is every reason to think the same tendency might have altered the outcome in Tolan.

A second possibility is that Plumhoff, as the sequel to Scott, remains the analytical norm, while Tolan and Thomas are outliers. Certainly Plumhoff better fits with the disposition of one similar case from the Term involving pretrial disposition of a civil-rights action and qualified immunity. ${ }^{11}$ This explanation is enhanced to the extent the Court muted Tolan's effect through procedural uncertainty. The Court's decision granting summary judgment against a plaintiff received plenary consideration and a fully precedential opinion, while decisions rejecting summary judgment against a plaintiff received less thorough, less forceful, and more confounded treatment. Even granting the Tolan per curiam some value, the differences in precedential and persuasive force are unavoidable. Moreover, the long-term consequence of both Tolan and Thomas depends not on the Supreme Court, but on what the lower courts do with the cases on remand. ${ }^{12}$

A third possibility is that none of these are about procedural standards on summary judgment, but instead are about underlying substantive considerations. Perhaps Tolan and Thomas are more significant as qualified immunity decisions. The real issue in both cases was how courts should define the factual context in determining whether a right is clearly established. Indeed, Judge Dennis specifically criticized the Fifth Circuit panel's approach to qualified immunity and the way it erroneously conflated distinct

110. Tolan, $134 \mathrm{~S}$. Ct. at 1866-68 (quoting Tolan v. Cotton, 713 F.3d 299, 305-08 (5th Cir. 2013)).

111. Wood v. Moss, 134 S. Ct. 2056, 2070 (2014).

112. See Tolan v. Cotton, 573 F. App'x 330, 331 (5th Cir. 2014) (holding that the defendant was not entitled to summary judgment on qualified immunity grounds from the excessive force claim and remanding to the district court); Thomas v. Nugent, 574 F. App'x 445, 445 (5th Cir. 2014) (remanding to the district court for reconsideration in light of the Supreme Court decision in Tolan). 
prongs of the analysis - rather than analyze whether Sergeant Cotton was legally mistaken as to the force he was permitted to use (the appropriate inquiry in asking whether a right is clearly established), the court analyzed the facts on the ground and considered whether the use of force was justified on those facts. ${ }^{113}$ In rejecting the panel's approach and implicitly adopting that of Judge Dennis, the Supreme Court was guiding lower courts on qualified immunity-do not collapse the two prongs of immunity analysis, whether by importing potential factual disputes into the second step or by conflating legal and factual considerations. Similarly, Plumhoff might not be about summary judgment standards, but about substantive Fourth Amendment concerns for when police can use deadly force to stop an ongoing high-speed chase that threatens public safety and, having decided to use force, the amount of force that is appropriate to end that chase.

\section{CONCLUSION}

As of this writing, the Supreme Court had no cases on its October Term 2014 docket obviously presenting questions of the proper standards or scope of summary judgment. As the summary judgment trilogy approaches its thirtieth anniversary, perhaps those standards are locked-in. Aside from pulling an outlier circuit into line, as in Tolan and Thomas, the real focus will be on substantive law and the application of substantive law in that procedural context. Hopefully this focus will lead to a better understanding and reliance on summary judgment in civil-rights litigation, particularly in the ever-increasing number of civil-rights cases featuring video evidence.

113. Tolan v. Cotton, 538 F. App'x 374, 376 (5th Cir. 2013) (Dennis, J., dissenting from denial of rehearing en banc). 
